Int. J. Dev. Biol. 57: 667-675 (2013)

doi: $10.1387 / \mathrm{ijdb} .130064 \mathrm{dd}$

\title{
Signaling pathways dictating pluripotency in embryonic stem cells
}

\author{
DEBASREE DUTTA* \\ Cancer Research Program, Rajiv Gandhi Centre for Biotechnology, Kerala, India
}

\begin{abstract}
Embryonic Stem Cells (ESCs) are derived from the inner cell mass of blastocysts. They have the unique potency to differentiate into diverse lineages. Hence, they are bestowed with the term pluripotency. Several mechanisms have been implicated in maintaining the pluripotency of ESCs. This review will focus on the role of signaling pathways in regulating ESC pluripotency among diverse mammalian species. A novel phylogenetic approach has been designed to understand the structural basis of divergence in the signaling pathways which modulate pluripotency among different species. Detailed insight into different signaling mechanisms indicates inhibition of Extracellular Related Kinase 1/2 (ERK 1/2) signaling as the key component regulating the pluripotency of ESCs. On the basis of recent advances made in this field, it can be hypothesized that expression of the transcription factor KLF4 and inhibition of ERK signaling may promote the establishment and maintenance of true ESCs from different mammalian species.
\end{abstract}

KEY WORDS: blastocyst, embryonic stem cell, signaling pathway, ERK, KLF4

\section{Introduction}

The process of embryogenesis is initiated with the fertilization of a sperm with an ovum. The one-celled embryo divides to form the blastocyst (Fig. 1) comprising of inner cell mass (ICM) and trophectoderm. Within the ICM, an epiblast layer of cells form the inner core sandwiched between polar trophblast and hypoblast cells (Fig. 1). This region further develops in vitro into ESC. Back in 1981, Evans and Kaufman were the first to derive mouse ESCs (mESCs) from the mouse blastocyst (Evans \& Kaufman, 1981). It took more than a decade to establish the first pluripotent human ESCs (hESCs) (Thomson et al., 1998) and primate ESCs (Thomson et al., 1995). ESCs have the inherent capacity to differentiate into any lineage and hence are termed as pluripotent. Also, they have the intrinsic potential to divide or self-renew indefinitely. These two characteristics formed the basis of exploiting ESCs for genetic manipulations (various genetic disorders) or in regenerative medicine and tissue replacement after injury or diseases. So, it is extremely significant to understand the mechanism responsible for the maintenance of pluripotency in ESCs.

Signaling molecules, transcription factors, cell cycle regulators and epigenetic modifications regulates intricate molecular mechanism of maintaining pluripotency of ESCs among wide range of mammalian species. Signaling mechanisms regulating the expression of pluripotency factors POU5F1, NANOG, SOX2 and KLF4 significantly differ in the context of species specification. Both extrinsic and intrinsic factors contribute towards the regulatory mechanisms involved in pluripotency. Extrinsic factors like Leukemia Inhibitory Factor (LIF), Bone morphogenic protein 4 (BMP4) or basic Fibroblast growth factor (bFGF) when supplemented to the ESC culture, induce signals that are transmitted through intracellular components and regulate the expression of pluripotency factors (Pera \& Tam, 2010). Intrinsic factors like ERK are present within the cell and in their active form generally induce the differentiation of mESCs. Hence, inhibition of these signaling pathways could maintain the pluripotency of mESCs.

ESCs have been isolated from mice to men. In spite of the importance of farm animals in agricultural and pharmaceutical application, the generation of true ESCs from these animals is still elusive. Animal models mimicking human anatomy are severely required to evaluate the safety and efficacy of cell therapies. But, due to technical problems in culturing and deriving ESCs from these animals and their inability to contribute to germ line, a detailed study on maintaining pluripotency of ESCs has been limited to fewer cases.

This review deals with signaling pathways implicated in maintain-

Abbreviations used in this paper: EpiSC, epiblast stem cell; ERK, extracellular related kinase; ESC, embryonic stem cell. *Address correspondence to: Debasree Dutta. Cancer Research Program, Rajiv Gandhi Centre for Biotechnology, Thycaud PO, Poojappura, Thiruvananthapuram,
Kerala, India 695014.Tel: 0471-252-9465. Fax: 0471-234-8096. E-mail: debasreedutta@ rgcb.res.in

ISSN: Online 1696-3547, Print 0214-6282 
ing pluripotency in ESCs isolated from different mammalian species. A novel phylogenetic approach has been included to provide a structural basis of the differential role of signaling pathways. The combinatorial role of a signaling pathway and transcription factor has been hypothesized to promote the maintenance and derivation of true ESCs from different mammalian species.

\section{Intrinsic factors in regulation of pluripotency}

\section{ERK signaling}

ESCs have an intrinsic property to differentiate spontaneously. So, inhibition of differentiation maintains the self-renewal character of mESCs. ERK1/2 signaling autoinductive stimulation by Fibroblast growth factor or FGF4 is implicated in inducing differentiation of mESCs. Suppression of FGF4/ERK signaling pathway promotes the self-renewal of mESCs (Ying et al., 2008). But, inhibition of FGF/ ERK signaling resulted in degeneration of $\mathrm{mESC}$ culture (Ying et al., 2008). So, to maintain metabolic activity, biosynthetic capacity and overall viability of mESCs, CHIR99021 $(\mathrm{CH})$ is introduced in the culture condition to (Ying et al., 2008) inhibit Glycogen synthase kinase 3 or GSK3 signaling. It could inhibit the differentiation towards neuronal lineage (Ying et al., 2008; Bechard \& Dalton, 2009) as well. Hence, dual inhibition of ERK and GSK3 signaling by PD0325901 (PD) and $\mathrm{CH}$ respectively restored the pluripotency in mouse as well as rat ESCs in a feeder free condition (Ying et al., 2008; Bechard \& Dalton, 2009; Buehr et al., 2008; Li et al., 2008).

Pluripotency in ESCs is maintained by a set of transcription factors. They function through feedback regulatory circuit positively regulating their own genes. These factors activate genes encoding critical components of pluripotency while repress genes important for developmental processes. Maintenance of self-renewal and pluripotency of ES cells require a complex network of transcription factors namely Pou5f1, Sox2 and Nanog (Niwa et al., 2000; Masui et al., 2007; Chambers et al., 2007; He et al., 2009). Another factor KIf4 was earlier found to be dispensable (Nakatake et al., 2006). But, a triple RNAi approach of knocking down Klf2, KIf4 and KIf5, established the role of Klfcircuitry in maintaining self-renewal state of mESCs (Jiang et al., 2008). ERK $1 / 2$ binds at the $\mathrm{C}$-terminal domain of KLF4 and phosphorylates it at Ser123 residue in mESCs (Kim

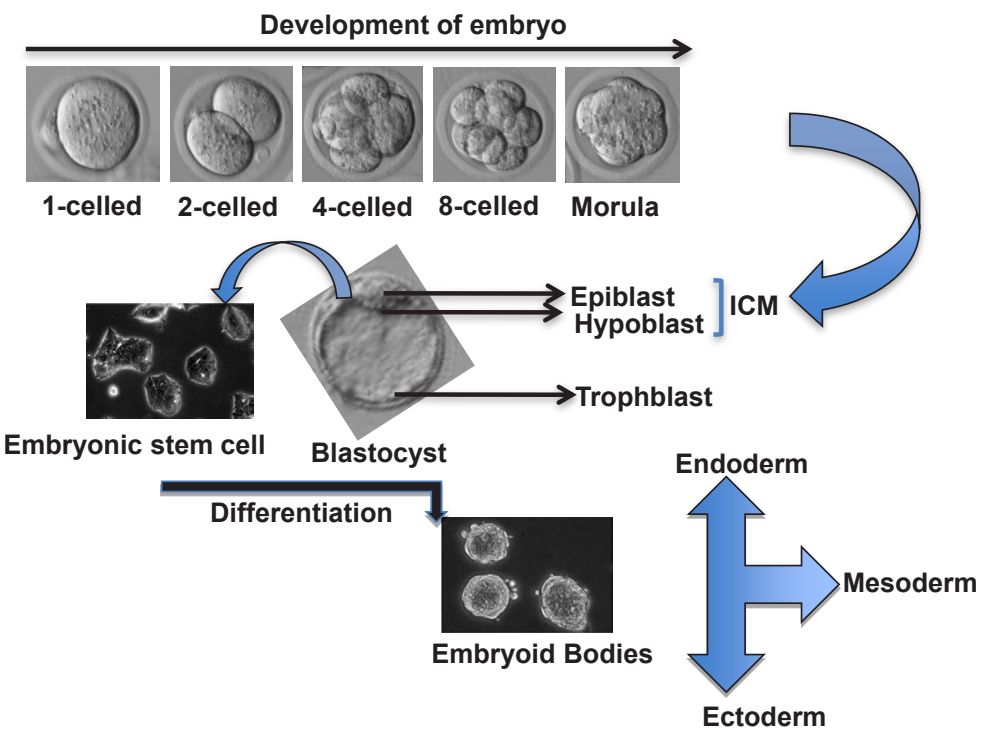

et al., 2012). This phosphorylation downregulate the transcriptional activity of KIf4 and induces differentiation of mESCs. Thus, inhibition of ERK signaling enhances Klf4 activity and in turn maintains the undifferentiated state of mESCs (Kim et al., 2012).

On the contrary, downstream to FGF signaling, activation of ERKsignaling is associated with maintenance of pluripotency in hESCs.

\section{PKC signaling}

Inhibition of protein kinase $\mathrm{C}(\mathrm{PKC})$ isoforms maintain pluripotency in mESCs without the activation of STAT3 or inhibition of ERK/GSK3 signaling pathways (Dutta et al., 2011). Atypical PKC isoform, $\mathrm{PKC \zeta}$ function is involved in the activation of $\mathrm{Nf} K b$ pathway during $\mathrm{mESC}$ differentiation. On inhibition of PKC signaling by the pharmacological drug, Gö6983, downregulation of Nfkbtargetgenes were observed (Dutta et al., 2011). Thus, an appropriate activity of PKC-signaling directly balances the self-renewal and differentiation status in mESCs and in rat ESCs as well (Rajendran et al., 2013).

\section{Aurora Kinase A/p53 signaling}

Phosphoregulators play a key role in signal transduction. Screening of shRNAs for mESC-associated phosphoregulators revealed an essential role of Aurora kinase A or Aurka in maintaining the self-renewal state of mESCs (Lee et al., 2012). Loss of Aurka is coupled to stimulation in p53 activity and hence induces differentiation of ESCs towards ectoderm and mesoderm lineage (Lee et al., 2012). Thus, Aurka mediated p53 phosphorylation is essential for maintaining self-renewal and pluripotency in mESCs. But, only future studies will establish whether the function of Aurka is conserved among species or not.

\section{Extrinsic factors in regulation of pluripotency}

\section{LIF and JAK/STAT3 signaling}

Mouse ESCs can be cultured in vitro in an undifferentiated state in presence of LIF and serum (Smith et al., 1988). LIF on binding to the receptor activates Janus kinase (JAK) and phosphorylates STAT3 at Tyr705 (Zhong et al., 1994; Niwa et al., 1998). STAT3 essentially maintains the c-MYC level (Cartwright et al., 2005) and induces the KLF4 expression (Hall et al., 2009) in mESCs. Additionally, Stat3 induced Pramel7 activity blocks the phosphorylation of ERK (Casanova et al., 2011). Recently zeta-chain (TCR) associated protein kinase or Zap70, a Syk (spleen tyrosine kinase) family tyrosine kinase, has been found to negatively regulate the JAK/STAT3/C-MYC pathway and thus modulate the self-renewal capacity and differentiation ability of mESCs (Cha et al., 2010). Zap70 interacts with SHP1 phosphatase and inhibits the phosphorylation of JAK, which in turn downregulate the STAT3 dependent c-MYC induction (Cha et al., 2010).

Interestingly, LIF is unable to maintain the undifferentiated state of hESCs. Rather, in pluripotent hESCs, STAT3 do not localize within the nucleus and is incapable to activate its target genes (Dahéron et al., 2004).

Fig. 1. Derivation and fate of Embryonic stem cells. Singlecelled embryo develops to form blastocyst composed of ICM and trophectoderm. ESCS are derived from the ICM and maintained in an undifferentiated state. Pluripotent ESCs differentiate into different lineages (endoderm, mesoderm and ectoderm) via the formation of embryoid bodies. 


\section{BMP4 signaling}

In absence of serum, LIF alone could not maintain the undifferentiated nature of mESCs. But when mESCs are cultured in presence of BMP4 and LIF, they retain the undifferentiated status (Ying et al., 2003). Dimeric BMP4 binds to type II receptor BMPR2 and facilitates the assembly of receptor heteromers (Yu et al., 2005). The constitutively active kinase domains of type II receptors phosphorylate type I receptors, BMPR1 (BMPR1A, earlier known as ALK3 or BMPR1B, earlier known as ALK6) and the type I receptors in turn phosphorylate either of the receptor SMADs (SMAD1or SMAD5 or SMAD8) (Heldin et al., 1997; Kawabata et al., 1998; Derynck \& Zhang, 2003). SMAD4 joins as the co-activator to either of the R-SMADs to form the heteromeric complex (Derynck \& Zhang, 2003). Phosphorylated receptor-SMAD induces the expression of $I d$ genes and represses genes implicated in neuroectoderm like Neurod, Ascl1 (Ying et al., 2003). Downstream to SMAD2, BMP4 signaling modulates the H3K27 demethyase, Kdm6b and Dihydropyrimidinase-like 2 or Dpysl2 in maintaining pluripotency of mESCs (Fei et al., 2010a).

Additionally, BMP4 can steadily attenuate the ERK activity by upregulating ERK-specific dual specificity phosphatase 9 (DUSP9) particularly in mESCs (Li et al., 2012; Qi et al., 2004).

Interestingly, the definite role of BMP4 in regulating pluripotency of hESCs is still unresolved. Earlier, it was demonstrated that BMP4 induces differentiation of hESCs towards extra-embryonic lineages specifically trophblasts and inclusion of Noggin in culture condition prevents the differentiation of hESCs towards the extra-embryonic lineage (Xu et al., 2002). But, in 2011, Bernardo et al., showed that BMP4 is responsible for the induction of differentiation towards mesoderm wherein the cells do express trophblast specific markers but to a lower extent (Bernardo et al., 2011). However, recently, Amita et al., reported the generation of trophoblast specific cells from hESCs in presence of only BMP4 (Amita et al., 2013). The differentiation was induced in a culture condition similar to the one used by Bernardo et al., (2011) although with a reduced level of expression of mesodermal markers. Hence, further validation is required to establish the role of BMP4 signaling in pluripotency of hESCs.

\section{Wnt/ $\beta$-catenin signaling}

The canonical Wnt-pathway has been implicated in pluripotency of mESCs. According to the newly established model of Wnt signaling, Wnt induces the association of the destruction complex composed of DVL1, AXIN, APC, GSK3 and phosphorylated $\beta$-catenin with phosphorylated LRP (Clevers \& Nusse, 2012). This complex phosphorylates $\beta$-catenin but further blocks the ubiquitination by $\beta$-TrCP. As a result, newly synthesized $\beta$-catenin is accumulated in the cytosol and translocated into the nucleus (Clevers \& Nusse, 2012). The $\beta$-catenin/CBP complex binds to its target Tcf and Lef and induces the expression of Stat3 mRNA (Miyabayashi et al., 2007; Hao et al., 2006). Independent of Tcf/Lef binding, stabilized $\beta$-catenin enhances Pou5f1 activity for the maintenance of pluripotency in mESCs (Kelly et al., 2011).

In hESCs, it was reported that activating the Wnt/ $\beta$-catenin pathway with either WNT3A or a GSK3 inhibitor, BIO ((2'Z,3'E)6-Bromoindirubin-3'-oxime), maintained the self-renewal of hESCs under feeder-free conditions (Sato et al., 2004). Conversely, there have been reports where WNT3A or GSK3 inhibitors lead to differentiation of hESCs toward primitive streak and definitive endoderm lineages (Bone et al., 2011; Nakanishi et al., 2009). So, the role of $\mathrm{Wnt} / \beta$-catenin signaling in hESCs is controversial. Recently, $W n t / \beta$-catenin signaling has been found to be inactive in the selfrenewal of hESCs (Davidson et al., 2012). During self-renewal in $\mathrm{hESCS}, \mathrm{POU} 5 \mathrm{~F} 1$ reportedly repress $\beta$-catenin signaling. So, targeted knockdown of POU5F1 activated $\beta$-catenin signaling in hESCs (Davidson et al., 2012). A fluorescent reporter of $\beta$-catenin revealed that the enhanced expression of $\beta$-catenin is associated with induced differentiation in hESCs (Davidson et al., 2012). Intriguingly, the fate of differentiation of hESCs corresponding to endogenous Wnt signaling is based on the heterogeneous culture of hESCs (Blauwkamp et al., 2012). Human ESCs with a higher expression of Wnt predominantly differentiated towards endodermal and cardiac fates whereas hESCs expressing lower level of Wnt generated cells primarily from neuroectodermal lineage.

This phenomenon further incites a very significant characteristic of ESCs, that is, heterogeneity in culture condition. Basically, this inherent property of ESCs further regulates the response towards different signaling mechanisms and hence will be discussed in a later section.

\section{FGF and Nodal/Activin signaling}

FGF signaling is associated with induction of differentiation in mouse and rat ESCs (Ying et al., 2008; Bechard \& Dalton, 2009). Activin/Nodal signaling has been reported to promote mESC proliferation (Ogawa et al., 2007) and has been implicated especially in commitment towards mesendoderm (Fei et al., 2010b).

But, FGF signaling could sustain the undifferentiated nature of hESCs. When cultured on feeder layers, hESCs maintain the undifferentiated state only in presence of bFGF (Thomson et al., 1998; Levenstein et al., 2006). Exogenously added bFGF binds to the FGF receptors and activate ERK1/2 signaling responsible for maintaining pluripotency in hESCs (Kang et al., 2005). FGF signaling also inhibits the spontaneous differentiation towards extra-embryonic lineage or neural-induction in hESCs (Greber et al., 2011). Exogenous addition of bFGF induces the expression of insulin growth factor II (IGF-II) from autologously derived hESC fibroblast-like cells (hdFs) (Bendall et al., 2007). The interaction between IGFR1/IGF-II contributes to the maintenance of stemness in hESCs (Bendall et al., 2007).

When cultured on MEFs, addition of bFGF further activates the Nodal/Activin signaling by activating Activin A receptors (Greber et al., 2007). Activin A receptors further phosphorylate SMAD2/3 and form a complex with co-activator SMAD4. The SMAD-complex induces the expression of NANOG in the nucleus and supports the maintenance of pluripotency of hESCs (Vallier et al., 2009a).

\section{PI3 kinase/AKT signaling}

Phosphoinositide 3-kinase (PI3K) pathway is important for proliferation, survival, and maintenance of pluripotency in ESC. On activation of $\mathrm{PI} 3 \mathrm{~K}$, secondary messengers are produced which transmit their effect through AKT, serine threonine kinase. AKT is implicated in different aspects of cellular metabolism and tumorigenesis. Earlier, a LIF-dependent activation of PI3K pathway was found to be responsible for regulating pluripotency in murine ESCs. On binding of LIF, gp130 is activated. The activated receptor then induces PI3K to phosphorylate PKB/AKT which in turn influences its downstream effectors to maintain the pluripotency in mESCs (Paling et al., 2004). Later, in 2006, the active myristolated form 
of AKT was reported to maintain ESC self-renewal independent of LIF or BMP4 or Wnt/ $\beta$-catenin signaling (Watanabe et al., 2006). Activated PI3K/AKT might inhibit GSK3 $\beta$ signaling and hence could maintain the pluripotency in mouse as well as in primate (monkey) ESCs (Watanabe et al., 2006).

Earlier reports suggested that inhibition of PI3K signaling promotes endodermal and mesodermal differentiation in hESCs (Mclean et al., 2007). But, recently it was demonstrated that in hESCs, PI3/AKT signaling promotes self-renewal by restricting pro-differentiation cues (Singh et al., 2012). In presence of IGF2/ Hergulin and Activin, hESC maintain the self-renewal state. IGF2/ Hergulin is responsible for the activation of PI3K/AKT signaling. Elevated PI3K/AKT activity induces SMAD2 and SMAD3 accumulation and the expression of the target gene NANOG (Singh et al., 2012). Additionally, AKT binding to c-RAF provokes dephosphorylation of ERK. This further inhibits the interaction of ERK with GSK3 resulting in its dephosphorylation. GSK3 signaling in turn inhibits the Wnt/ $\beta$-catenin pathway (Singh et al., 2012) and thus maintains the undifferentiated state of hESCs. Hence the crosstalk between different signaling pathways could mediate pluripotency in hESCs.

\section{Signaling pathways implicated in pluripotency of ESCs from other animals}

Even after 30 years of the first successful derivation of mESC (Evans \& Kaufmann, 1981), no convincing pluripotent embryonic stem cells have been reproducibly established from non-rodent or non-primates. Present literature demonstrates the establishment of only ES-like cell lines from these animals as they are deprived of major characters associated with pluripotency or true chimerism (Gandolfi et al., 2012). Different porcine, canine, rabbit, bovine, ovine and cat ES like cells were isolated and cultured. Most of these ES like cells thrive on bFGF signaling for maintenance of pluripotency. Based on the response towards bFGF signaling, they might resemble hESCs rather than mESCs. Signaling pathways implicated in maintaining pluripotency of ES-like cells from diverse mammalian species have been summarized in Table 1. Interestingly, few ES-like cell lines from these domesticated animals require both bFGF and LIF for the maintenance of pluripotency. So, Gandolfi et. al. in a recent review concluded that a synergistic action of bFGF and LIF on the expression of NANOG promoted the derivation of ES-like cells (Gandolfi et al., 2012). As robust ESCs from these species are difficult to derive and maintain, so somatic cells from these species have been reprogrammed to induced pluripotent stem cells (iPSCs) with different set of genes (Takahashi et al., 2007). Most frequently but not exclusively, four genes OCT4, SOX2, KLF4 and $c-M Y C$ are expressed in these somatic cells like fibroblast to generate iPSCs. These cells exhibit a pluripotent phenotype resembling ESCs and hence can be used as an alternative to study pluripotency within these species. A recent review by Ezhashi et al., has summarized the characteristics of different set of iPSC lines generated from these animals (Ezhashi et al., 2012).

\section{Structural aspect for divergence}

Different signaling mechanisms are implicated in maintaining pluripotency among a wide range of mammalian species. As mentioned earlier, recent evidences indicated that culture of ESCs is a heterogeneous mix of population of cells representing different state and thus fluctuate in the potency to differentiate into different lineages. This heterogeneity is present in both mESCs (Hayashi et al., 2008) and hESCs (Hough et al., 2009). Signaling molecules invoke varied responses from these heterogeneous population of cells in culture condition. But, in a broader sense, hESCs differ from $\mathrm{mESC}$ in various aspects including colony morphology, capacity for colonizing pre-implantation embryo, epigenetic stability among others. Intriguingly, hESCs share common gene expression pattern and signaling responses to stems cells isolated from late epiblast layer of post-implantation mouse embryo, called Epiblast stem cells or EpiSCs (Brons et al., 2007; Tesar et al., 2007). The $\mathrm{mEpiSC}$ lines are distinctively different from mESCs both in their epigenetic state as well as signaling responses regulating their differentiation. Mouse EpiSCs maintain the genomic integrity and can be propagated to major somatic cell types. Unlike mESCs

TABLE 1

\section{SIGNALING PATHWAYS IN MAINTAINING PLURIPOTENCY OF ESCs AND ES-LIKE CELLS}

\begin{tabular}{|c|c|c|c|c|c|c|c|c|c|c|c|c|}
\hline \multirow[b]{2}{*}{ Signaling pathways } & \multicolumn{11}{|c|}{ Species } & \multirow[b]{2}{*}{ References } \\
\hline & Mouse & Rat & Rabbit & Dog & Cat & Horse & Pig & Sheep & Bovine & Monkey & Human & \\
\hline \multicolumn{13}{|l|}{ Factors intrinsic } \\
\hline FGF/ERK & $\mathrm{D} / \mathrm{I}$ & $\mathrm{D} / \mathrm{I}$ & $\mathrm{D} /-$ & ND & ND & ND & ND & ND & ND & ND & $\mathrm{D} / \mathrm{A}$ & $\begin{array}{l}\text { Ying et al. 2008; Buehr et al. 2008; Li et al. 2008; He et al. 2009; Greber et } \\
\text { al. 2011; Honda et al. } 2009\end{array}$ \\
\hline GSK3 & $\mathrm{D} / \mathrm{I}$ & $\mathrm{D} / \mathrm{l}$ & ND & ND & ND & ND & ND & ND & ND & ND & $\mathrm{D} / \mathrm{l}$ & $\begin{array}{l}\text { Ying et al. 2008; Bechard \& Dalton et al. 2009; Buehr et al. 2008; Singh et } \\
\text { al. } 2012\end{array}$ \\
\hline PKC & $\mathrm{D} / \mathrm{l}$ & $\mathrm{D} / \mathrm{I}$ & ND & ND & ND & ND & ND & ND & ND & ND & ND & Dutta et al. 2011; Rajendran et al. 2013 \\
\hline Arora Kinase A/p53 & $\mathrm{D} / \mathrm{A}$ & ND & ND & ND & ND & ND & ND & ND & ND & ND & ND & Lee et al. 2012 \\
\hline \multicolumn{13}{|l|}{ Factors extrinsic } \\
\hline LIF and JAK/STAT & $\mathrm{D} /+$ & $\mathrm{D} /-$ & $\mathrm{D} /+/-$ & $\mathrm{D} /+/-$ & $\mathrm{D} /+/-$ & $\mathrm{D} /+$ & $\mathrm{D} /+/-$ & $\mathrm{D} /+/-$ & $\mathrm{D} /-$ & $\mathrm{D} /-$ & $\mathrm{D} /-$ & $\begin{array}{l}\text { Evans \& Kaufman, 1981; He et al. 2009; Pera \& Tam, 2010; Daheron et al. } \\
\text { 2004; Telugu et al. 2011; Behboodi et al. 2011; Saito et al. 2002; Hayes et } \\
\text { al. 2008; Maruotti et al. 2012; Gandolfi et al. 2012; Zhao et al. 2011 }\end{array}$ \\
\hline BMP4/Smad & $\mathrm{D} /+$ & $\mathrm{D} /-$ & $\mathrm{D} /-$ & $\mathrm{D} /-$ & ND & ND & ND & ND & ND & $\mathrm{D} /-$ & $\mathrm{D} /-$ & $\begin{array}{l}\text { Ying et al. 2003; Tan et al. 2011; Kobayashi et al. 2008; Ueda et al. 2008, } \\
\text { Xu et al. } 2002\end{array}$ \\
\hline Wnt/ $\beta$-catenin & $\mathrm{D} /+$ & ND & $\mathrm{D} /-$ & ND & ND & ND & ND & ND & ND & ND & $\mathrm{D} /-$ & $\begin{array}{l}\text { Miyabayashi et al. 2007; Davidson et al. 2012; Hoffmeyer et al. 2012; Wang } \\
\text { et al. } 2008\end{array}$ \\
\hline bFGF/Activin/Nodal & $\mathrm{D} /-$ & ND & $\mathrm{D} /+$ & $\mathrm{D} /+$ & $\mathrm{D} /+$ & $\mathrm{D} /-$ & $\mathrm{D} /+$ & $\mathrm{D} /+$ & $\mathrm{D} /+$ & ND & $\mathrm{D} /+$ & $\begin{array}{l}\text { Fei et al. 2010; Levenstein et al. 2006;, Gandolfi et al. 2012; Honda et al. } \\
\text { 2009; Hayes et al. 2008; Zhao et al. } 2011\end{array}$ \\
\hline PI3K/AKT & $D /+$ & ND & ND & ND & ND & ND & ND & ND & ND & $D /+$ & $\mathrm{D} /+$ & Paling et al. 2004; Watanabe et al. 2006; Singh et al. 2012 \\
\hline
\end{tabular}

D- Determined; ND- Not Determined; I- Inhibition; A- Activation; + positively modulate; +/- positively modulate but need other factors; - negatively modulate by inducing differentiation. 
but alike hESCs, mEpiSCs are derived and cultured in presence of bFGF/Activin (Brons et al., 2007; Tesar et al., 2007; Grebar et al., 2010). The pluripotency of mEpiSCs is associated with the expression of classical pluripotent markers, Nanog, Pou5f1 and Sox2 (Brons et al., 2007; Tesar et al., 2007). Hence, a proper characterization of the pluripotent state of mEpiSCs would further enhance our understanding of hESCs. A comparative study of differential characteristics among hESCs vs. mEpiSCs is summarized in Table 2. Mouse EpiSCs culture comprises of both early and late epiblast cells (Han et al., 2010). They express different sets of markers and accordingly, only the minor fraction of early EpiSCs contribute to chimera (Han et al., 2010). This further emphasizes the importance of heterogeneity in culture conditions.

ESCs from species other than mouse and rat might represent the pluripotent state of mEpiSC, as they resemble hESCs. Thus, two distinct phases exist in pluripotency: one that is represented by mESCs is referred as naïve state while the other corresponding to EpiSCs is referred as primed state (Nichols \&Smith, 2009, 2011; De Los Angeles et al., 2012). The naïve state refers to those cells that contribute towards the chimeric embryo, maintain $X$ chromosome activation in the female cells and are comparatively refractory to differentiate towards primordial germ cells or PGCs (Nichols \& Smith, 2009, 2011). They can be cloned with high efficiency, form dome shaped colonies, are responsive to LIF/STAT3 signaling and destabilized by bFGF and TGF $\beta /$ Activin signaling (Nichols \& Smith, 2009, 2011). On the contrary, primed pluripotent state refers to those cells that have a limited capacity for colonizing preimplantation embryo; undergone $\mathrm{X}$ chromosome inactivation (XiXa) within the female cells and is poised for differentiation to PGCs (Nichols \& Smith, 2009, 2011). Their clonal propagation is inefficient, form flattened colonies, are stabilized by bFGF and TGF $\beta$ /Activin signaling and are non-responsive to LIF/STAT3 signaling (Nichols \& Smith, 2009, 2011). Human ESCs sharing similar characteristics with mEpiSCs, represent the primed state. Even ESCs from Rhesus monkey exist in the primed state of pluripotency as they failed to colonize the pre-implantation blastocyst (Tachibana et al., 2012). So, in effect, the derivation of naïve ESCs from domesticated animals and primates still remain

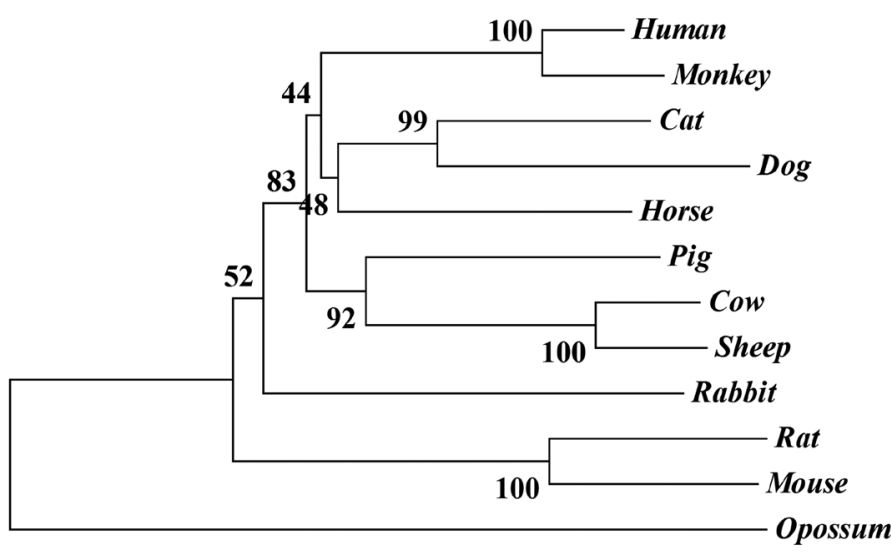

\subsection{1}

Fig. 2. Phylogenetic tree: point of divergence. Phylogenetic relationship among mammals based on Stat3 gene sequences. The phylogenetic tree is deduced using Mega (Kumar et al., 2004) software after multiple alignments of gene sequences with ClustalW (Thompsonetal., 1994). Distances (distance options according to the Jukes-Cantor model) and clustering with the neighbour-joining method was determined by using bootstrap values (Felsenstein, 1985) based on 100 replications. The Stat3 sequence from Opossum is used as the outgroup. Numbers at nodes indicate bootstrap values. Bar, 1 substitution per 100 nucleotides.

elusive. Mouse ESCs are considered to present the naïve state of pluripotency, but while in culture, an intermediate population called intermediate epiblast state cells (IESCs) has been found to exist (Chang \& Li, 2013). IESCs are responsive towards both LIF/ STAT3 as well as Activin/Smad2/3 signaling (Chang \& Li, 2013). So, even naïve $\mathrm{mESC}$ are prone to spontaneous differentiation to an intermediate state corresponding to neither naïve nor primed.

Depending on the differential responses of ESCs or ES-like cells to LIF/STAT3 signaling, a phylogenetic approach has been designed to understand the structural basis of this divergence among different mammalian species. Multigene and multiprotein

TABLE 2

\section{HUMAN ESCs vs. MOUSE EpiSCs}

\begin{tabular}{|c|c|c|c|}
\hline & Human ESCs & Mouse EpiSCs & References \\
\hline \multicolumn{4}{|l|}{ Characteristics (differential) } \\
\hline Source & Peri-implantation embryo & Post-implantation as well as pre-implantation embryo & Thompson et al. 1998; Brons et al. 2007; Tesar et al. 2007 \\
\hline Chimera generation & No & $\begin{array}{l}\text { Only with pre-implantation (E5.5) and not from post- } \\
\text { implantation (E6.5/E7.5) }\end{array}$ & $\begin{array}{l}\text { Thompson et al. 1998; Brons et al. 2007; Tesar et al. 2007; Najm et al. } \\
2011\end{array}$ \\
\hline KLF4 & Expressed & Virtually absent or weakly present & Nichols \& Smith, 2009; Chan et al. 2009 \\
\hline REX1 & Expressed & Absent & Greber et al. 2010 \\
\hline FGF5 & Absent & Expressed & Greber et al. 2010 \\
\hline \multicolumn{4}{|l|}{ Signaling pathway } \\
\hline LIF and JAK/STAT3 & Independent & Independent & Dahèron et al. 2004; Brons et al. 2007; Tesar et al. 2007 \\
\hline BMP4 & $\begin{array}{l}\text { Differentiate towards } \\
\text { trophblast or mesoderm }\end{array}$ & Differentiate towards extraembryonic cells & $\begin{array}{l}\text { Xu et al. 2002; Blauwkamp et al. 2012; Amita et al., 2013; Tesar et al. } \\
2007\end{array}$ \\
\hline BMP4 (High Activin \& bFGF) & Mesendoderm & Mesendoderm & Vallier et al. $2009 \mathrm{~b}$ \\
\hline bFGF in pluripotency & Induces NANOG expression & $\begin{array}{l}\text { Inhibits differentiation towards neuroectoderm and } \\
\text { reversion to mESC by suppressing KLF2 }\end{array}$ & Greber et al. 2011; Greber et al. 2010 \\
\hline $\begin{array}{l}\text { bFGF in differentiation (-Activin \& } \\
\text { BMP) }\end{array}$ & Neuroectoderm & Neuroectoderm & Vallier et al. 2009b \\
\hline bFGF/Activin/Nodal & Maintain Pluripotency & Maintain Pluripotency & Thompson et al. 1998; Brons et al. 2007; Tesar et al. 2007 \\
\hline FGF/ERK inhibition & Death or differentiation & Revert to mESCs & Nichols \& Smith, 2009; Guo et al. 2009; Roode et al. 2012 \\
\hline
\end{tabular}


studies revealed that phylogenetically, human and monkeys are the nearest relative to the rodents while they are distantly related to the domesticated animals (Hedges, 2002). But, the phylogenetic tree derived from the alignment of Stat3 gene sequences represents a different picture (Fig. 2). The phylogenetic tree in Fig.2 demonstrates that human and monkeys are closer to the farm animals and not rodents. Even rabbit branches with the cluster composed of these farm animals rather than the rodents. As ES like cells from domesticated animals resemble the hESCs and are responsive to bFGF signaling, this phylogenetic relationship further suggests that they might be distinct from mESCs. Hence, the phylogenetic tree predicts that unless manipulated, ESCs from the domesticated animals and rabbit might not respond to the LIF/ STAT3 signaling (Fig. 2). Thus, the structural basis demonstrating a probable picture of deviation in signaling pathways implicated in pluripotency among diverse mammalian species could replicate the experimental findings.

\section{Common pathway in deriving and culturing true ESCs?}

So, the next question arises that in spite of spending a considerable effort on deriving and culturing ESCs from livestock for decades, what is the basic hurdle in achieving the promise of true stem cells in agriculture and how can we conquer it? The answer might lie in the fact that there is a basic difference in the development of embryo within different mammalian species (Nichols \& Smith, 2009). During early development of embryo, the opportunity for capturing the transient ground state in non-rodents is minimized as compared to rodents (Nichols \& Smith, 2009). Additionally, absence of diapause in primates further alleviates ESC derivation (Nichols \& Smith, 2009). Despite this hurdle in generating naïve pluripotency, number of successful in vitro experiments has been performed to revert primed state into naïve state. Re-expression of the transcription factor KLF4 is essential in the regeneration of naïve mESCs from primed mEpiSCs (Guo et al., 2009) or naïve hESCs from primed hESCs (Hanna et al., 2010). Forskolin or Kellpaullone are used in culture during reversion from primed to naïve state to induce the KLF4 expression (Hanna et al., 2009, 2010). Downstream to JAK/STAT3 signaling, an induced KIf4 expression along with Pou5f1 could establish and maintain naïve pluripotency (van Oosten et al., 2012). Additionally, KLF4 regulate the TERT subunit of telomerase, which is required for the maintenance of pluripotency in mESCs (Hoffmeyer et al., 2012). Intriguingly, true porcine ESCs have been derived by the overexpression of KLF4 in the ICM of pig blastocyst (Telugu et al., 2011). These experimental evidences strongly justify the substantial role of Klf4 in isolating or maintaining true stemness of ESCs. Expression of KIf4 is further regulated by ERK signaling (Kim et al., 2012). In addition to Klf4 regulation, inhibition of ERK signaling is associated with the existence of mESCs in ground state of pluripotency (Nichols et al., 2009). In non-permissive NOD mouse strain, inhibition of ERK/ GSK3 (2i) signaling enabled the derivation of naïve mESCs (Hanna et al., 2009). Inhibition of ERK signaling is even associated with LIF/STAT3 or BMP4/SMAD signaling or in the biallelic expression of Nanog in mESCs (Miyanari \& Torres-Padilla, 2012).

On the other hand, inhibition of ERK signaling promotes death or differentiation in hESCs (Nichols \& Smith, 2009; Guo et al., 2009). But interestingly, inhibition of ERK signaling has been found to promote establishment of naïve hESCs from primed hESCs or in the generation of naïve hiPSCs. Yamanaka factors, especially KLF4, along with LIF/2i could generate mESC-like hiPSCs (Hanna et al., 2009) while, generation of FGF2-dependent hiPSC is independent of KLF4 expression (Huangfu et al., 2008).

Intriguingly, inhibition of ERK signaling is responsible for the establishment of ground state of pluripotency from the mouse blastocyst. But this role of ERK signaling has been found to be highly species specific. The epiblast/hypoblast differentiation from the common ICM precursor is dependent on FGF/ERK signaling in mouse (Feldman et al., 1995). An inhibition of ERK signaling induces NANOG expression in the epiblast cells and shuts off GATA6 in the hypoblast cells (Feldman et al., 1995). In bovine blastocyst, ERK inhibition could induce NANOG expression without affecting hypoblast formation (Kuijk et al., 2012). But, the segregation of hypoblast from epiblast in human embryo is independent of FGF signaling (Roode et al., 2012). On inhibition of ERK signaling, there is no repression of GATA4 expression. Interestingly, without any deteriorating effect, $2 \mathrm{i}$ could still retain the NANOG positive epiblast cells (Roode et al., 2012). This observation significantly indicates that FGF/ERK signaling independent derivation of naïve hESCs might be possible in future.

\section{Conclusion}

Defined intrinsic and extrinsic regulations contribute to the maintenance of pluripotency in ESCs from different species. But, neither of them could be universally implicated in maintaining the self-renewal or pluripotent state of ESCs from the entire range of mammalian species. Supported by experimental evidences, this review hypothesized that an induced expression of KLF4 in the ICM of non-permissive strains of non-rodent/primate/human blastocyst followed by an inhibition of ERK signaling might promote naïve state of pluripotency in ESCs. The requirement of a combinatorial action of these two factors is reflected even during the reversion of primed EpiSCs to naïve ESCs. In future, it will be highly significant to understand how ERK signaling and KLF4 overexpression could induce the generation of naïve state of pluripotency in hESCs.

\section{Acknowledgement}

This work is partially supported by grant from Department of Biotechnology, India (\#BT/PR5754/MED/31/167/2012). I thank Dr. Ananda Mukherjee for his critical comment on the manuscript.

\section{References}

AMITA M, ADACHI K, ALEXENKO AP, SINHA S, SCHUST DJ, SCHULZ LC, ROBERTS RM, EZASHI T (2013). Complete and unidirectional conversion of human embryonic stem cells to trophoblast by BMP4. Proc Natl Acad Sci USA 110: E1212-1221.

BECHARD M, DALTONS (2009). Subcellular localization of glycogen synthase kinase 3beta controls embryonic stem cell self-renewal. Mol Cell Biol 29: 2092-2104.

BEHBOODI E, BONDAREVAA, BEGIN I, RAO K, NEVEU N, PIERSON JT, WYLIE C, PIERO FD, HUANG YJ, ZENG W, TANCO V, BALDASSARRE H, KARATZAS CN, DOBRINSKI I (2011). Establishment of goat embryonic stem cells from in vivo produced blastocyst-stage embryos. Mol Reprod Dev 78: 202-211.

BENDALL SC, STEWART MH, MENENDEZ P, GEORGE D, VIJAYARAGAVAN K, WERBOWETSKI-OGILVIE T, RAMOS-MEJIA V, ROULEAU A, YANG J, BOSSÉ M, LAJOIE G, BHATIAM (2007). IGF and FGF cooperatively establish the regulatory stem cell niche of pluripotent human cells in vitro. Nature 448: 1015-1021.

BERNARDO AS, FAIAL T, GARDNER L, NIAKAN KK, ORTMANN D, SENNER CE, CALLERY EM, TROTTER MW, HEMBERGER M, SMITH JC, BARDWELL L, 
MOFFETT A, PEDERSEN RA (2011). BRACHYURY and CDX2 mediate BMPinduced differentiation of human and mouse pluripotent stem cells into embryonic and extraembryonic lineages. Cell Stem Cell 9: 144-155.

BONE HK, NELSON AS, GOLDRING CE, TOSH D, WELHAM MJ (2011). A novel chemically directed route for the generation of definitive endoderm from human embryonic stem cells based on inhibition of GSK-3. J Cell Sci 124: 1992-2000.

BLAUWKAMP TA, NIGAM S, ARDEHALI R, WEISSMAN IL, NUSSE R (2012). Endogenous Wnt signalling in human embryonic stem cells generates an equilibrium of distinct lineage-specified progenitors. Nat Commun 3: 1070.

BRONS IG, SMITHERS LE, TROTTER MW, RUGG-GUNN P, SUN B, CHUVA DE SOUSA LOPES SM, HOWLETT SK, CLARKSON A, AHRLUND-RICHTER L, PEDERSEN RA, VALLIER L (2007). Derivation of pluripotent epiblast stem cells from mammalian embryos. Nature 448: 191-195.

BUEHR M, MEEK S, BLAIR K, YANG J, URE J, SILVA J, MCLAY R, HALL J, YING QL, SMITH A (2008). Capture of authentic embryonic stem cells from rat blastocysts. Cell 135: 1287-1298

CARTWRIGHT P, MCLEAN C, SHEPPARD A, RIVETT D, JONES K, DALTON S (2005). LIF/STAT3 controls ES cell self-renewal and pluripotency by a Mycdependent mechanism. Development 132: 885-896.

CASANOVA EA, SHAKHOVA O, PATEL SS, ASNER IN, PELCZAR P, WEBER FA, GRAF U, SOMMER L, BÜRKI K, CINELLI P (2011). Pramel7 mediates LIF/ STAT3-dependent self-renewal in embryonic stem cells. Stem Cells 29:474-485.

CHA Y, MOON BH, LEE MO, AHN HJ, LEE HJ, LEE KA, FORNACE AJ JR, KIM KS, CHA HJ, PARK KS (2010). Zap70 functions to maintain stemness of mouse embryonic stem cells by negatively regulating Jak $1 /$ Stat3/c-Myc signaling. Stem Cells 28: 1476-1486.

CHAMBERS I, SILVA J, COLBY D, NICHOLS J, NIJMEIJER B, ROBERTSON M, VRANA J, JONES K, GROTEWOLD L, SMITH A (2007). Nanog safeguards pluripotency and mediates germline development. Nature 450: 1230-1234.

CHAN KK, ZHANG J, CHIA NY, CHAN YS, SIM HS, TAN KS, OH SK, NG HH, CHOO AB (2009). KLF4 and PBX1 directly regulate NANOG expression in human embryonic stem cells. Stem Cells 27: 2114-2125.

CHANG KH, LI M (2013). Clonal isolation of an intermediate pluripotent stem cell state. Stem Cells 31: 918-927.

CLEVERS H, NUSSE R (2012). Wnt/ק-catenin signaling and disease. Cell 149: 1192-1205.

DAHÉRON L, OPITZ SL, ZAEHRES H, LENSCH MW, ANDREWS PW, ITSKOVITZELDOR J, DALEY GQ (2004). LIF/STAT3 signaling fails to maintain self-renewal of human embryonic stem cells. Stem Cells 22: 770-778.

DAVIDSON KC, ADAMS AM, GOODSON JM, MCDONALD CE, POTTER JC, BERNDT JD, BIECHELE TL, TAYLOR RJ, MOON RT (2012). Wnt/ $\beta$-catenin signaling promotes differentiation, not self-renewal, of human embryonic stem cells and is repressed by Oct4. Proc Natl Acad Sci USA 109: 4485-4490.

DE LOS ANGELES A, LOH YH, TESAR PJ, DALEY GQ (2012). Accessing naïve human pluripotency. Curr Opin Genet Dev 22: 272-282.

DERYNCK R, ZHANG YE (2003). Smad-dependent and Smad-independent pathways in TGF-beta family signalling. Nature 425: 577-584.

DUTTA D, RAY S, HOME P, LARSON M, WOLFE MW, PAUL S (2011). Self-renewal versus lineage commitment of embryonic stem cells: protein kinase $C$ signaling shifts the balance. Stem Cells 29: 618-628.

EVANS MJ, KAUFMAN MH (1981). Establishment in culture of pluripotential cells from mouse embryos. Nature 292: 154-156.

EZASHI T, TELUGU BP, ROBERTS RM (2012). Induced pluripotent stem cells from pigs and other ungulate species: An alternative to embryonic stem cells? Reprod Domest Anim 47: 92-97.

FEI T, XIA K, LI Z, ZHOU B, ZHU S, CHEN H, ZHANG J, CHEN Z, XIAO H, HAN JD, CHEN YG (2010a). Genome-wide mapping of SMAD target genes reveals the role of BMP signaling in embryonic stem cell fate determination. Genome Res 20: 36-44.

FEI T, ZHU S, XIA K, ZHANG J, LI Z, HAN JD, CHEN YG (2010b). Smad2 mediates Activin/Nodal signaling in mesendoderm differentiation of mouse embryonic stem cells. Cell Res 20: 1306-1318.

FELDMAN B, POUEYMIROU W, PAPAIOANNOU VE, DECHIARA TM, GOLDFARB M (1995). Requirement of FGF-4 for postimplantation mouse development. Science 267: 246-249.
FELSENSTEIN J (1985). Confidence limits on phylogenies: an approach using the bootstrap. Evolution 39: 783-791.

GANDOLFI F, PENNAROSSA G, MAFFEI S, BREVINI T (2012). Why is it so difficult to derive pluripotent stem cells in domestic ungulates? Reprod Domest Anim 47: 11-17.

GREBER B, COULON P, ZHANG M, MORITZ S, FRANK S, MÜLLER-MOLINAAJ, ARAÚZO-BRAVO MJ, HAN DW, PAPE HC, SCHÖLER HR (2011). FGF signalling inhibits neural induction in human embryonic stem cells. EMBO J30: 4874-4884.

GREBER B, LEHRACH H, ADJAYE J (2007). Fibroblast growth factor 2 modulates transforming growth factor beta signaling in mouse embryonic fibroblasts and human ESCs (hESCs) to support hESC self-renewal. Stem Cells 25: 455-464.

GREBER B, WU G, BERNEMANN C, JOO JY, HAN DW, KO K, TAPIAN, SABOUR D, STERNECKERT J, TESAR P, SCHÖLERHR (2010). Conserved and divergent roles of FGF signaling in mouse epiblast stem cells and human embryonic stem cells. Cell Stem Cell 6: 215-226.

GUO G, YANG J, NICHOLS J, HALL JS, EYRES I, MANSFIELD W, SMITH A (2009). Klf4 reverts developmentally programmed restriction of ground state pluripotency. Development 136: 1063-1069.

HALLJ, GUO G, WRAY J, EYRESI, NICHOLS J, GROTEWOLD L, MORFOPOULOU $S$, HUMPHREYS P, MANSFIELD W, WALKER R, TOMLINSON S, SMITH A (2009). Oct4 and LIF/Stat3 additively induce Krüppel factors to sustain embryonic stem cell self-renewal. Cell Stem Cell 5: 597-609.

HAN DW, TAPIA N, JOO JY, GREBER B, ARAUZO-BRAVO MJ, BERNEMANN C, KO KINARM, WU GUANGMING, STEHLING M, DO JT, SCHÖLER HR (2010). Epiblast stem cell subpopulations represent mouse embryos of distinct pregastrulation stages. Cell 143: 617-627.

HANNA J, CHENG AW, SAHA K, KIM J, LENGNER CJ, SOLDNER F, CASSADY JP, MUFFAT J, CAREY BW, JAENISCH R (2010). Human embryonic stem cells with biological and epigenetic characteristics similar to those of mouse ESCs. Proc Natl Acad Sci USA 107: 9222-9227.

HANNA J, MARKOULAKI S, MITALIPOVA M, CHENG AW, CASSADY JP, STAERK J, CAREY BW, LENGNER CJ, FOREMAN R, LOVE J, GAO Q, KIM J, JAE$\mathrm{NISCH}$ R (2009). Metastable pluripotent states in NOD-mouse-derived ESCs. Cell Stem Cell 4: 513-524

HAO J, LI TG, QI X, ZHAO DF, ZHAO GQ (2006). WNT/beta-catenin pathway up-regulates Stat3 and converges on LIF to prevent differentiation of mouse embryonic stem cells. Dev Biol 290: 81-91.

HAYASHI K, LOPES SM, TANG F, SURANI MA (2008). Dynamic equilibrium and heterogeneity of mouse pluripotent stem cells with distinct functional and epigenetic states. Cell Stem Cell 3: 391-401.

HAYES B, FAGERLIE SR, RAMAKRISHNAN A, BARAN S, HARKEY M, GRAF L, BAR M, BENDORAITE A, TEWARI M, TOROK-STORB B (2008). Derivation, characterization, and in vitro differentiation of canine embryonic stem cells. Stem Cells 26: 465-473.

HE S, NAKADA D, MORRISON SJ (2009). Mechanisms of stem cell self-renewal. Ann Rev Cell Dev Biol 25: 377-406.

HEDGES SB (2002). The origin and evolution of model organisms. Nat Rev Genet 3: 838-849.

HOFFMEYER K, RAGGIOLI A, RUDLOFF S, ANTON R, HIERHOLZER A, DEL VALLE I, HEIN K, VOGT R, KEMLERR (2012). Wnt/ $\beta$-catenin signaling regulates telomerase in stem cells and cancer cells. Science 336: 1549-1554.

HELDIN CH, MIYAZONO K, TEN DIJKE P (1997). TGF-beta signalling from cell membrane to nucleus through SMAD proteins. Nature 390: 465-471.

HONDA A, HIROSE M, OGURA A (2009). Basic FGF and Activin/Nodal but not LIF signaling sustain undifferentiated status of rabbit embryonic stem cells. Exp Cell Res 315: 2033-2042.

HOUGH SR, LASLETT AL, GRIMMOND SB, KOLLE G, PERA MF (2009). A continuum of cell states spans pluripotency and lineage commitment in human embryonic stem cells. PLoS One 4: e7708.

HUANGFU D, OSAFUNE K, MAEHR R, GUO W, EIJKELENBOOM A, CHEN S, MUHLESTEIN W, MELTON DA (2008). Induction of pluripotent stem cells from primary human fibroblasts with only Oct4 and Sox2. Nat Biotechnol26: 1269-1275.

JIANG J, CHAN YS, LOH YH, CAI J, TONG GQ, LIM CA, ROBSON P, ZHONG S, $\mathrm{NG} \mathrm{HH} \mathrm{(2008).} \mathrm{A} \mathrm{core} \mathrm{Klf} \mathrm{circuitry} \mathrm{regulates} \mathrm{self-renewal} \mathrm{of} \mathrm{embryonic} \mathrm{stem}$ cells. Nat Cell Biol 10: 353-360. 
KANG HB, KIM JS, KWON HJ, NAM KH, YOUN HS, SOK DE, LEE Y (2005). Basic fibroblast growth factor activates ERK and induces c-fos in human embryonic stem cell line MizhES1. Stem Cells Dev 14: 395-401.

KAWABATA M, IMAMURA T, MIYAZONO K (1998). Signal transduction by bone morphogenetic proteins. Cytokine Growth Factor Rev 9: 49-61.

KELLY KF, NG DY, JAYAKUMARAN G, WOOD GA, KOIDE H, DOBLE BW (2011). $\beta$-catenin enhances Oct-4 activity and reinforces pluripotency through a TCFindependent mechanism. Cell Stem Cell 8: 214-227.

KIM MO, KIM SH, CHO YY, NADAS J, JEONG CH, YAO K, KIM DJ, YU DH, KEUM YS, LEE KY, HUANG Z, BODE AM, DONG Z (2012). ERK1 and ERK2 regulate embryonic stem cell self-renewal through phosphorylation of KIf4. Nat Struct Mol Biol 19: 283-290.

KOBAYASHI M, TAKADAT, TAKAHASHIK, NODAY, TORII R (2008). BMP4 induces primitive endoderm but not trophectoderm in monkey embryonic stem cells. Cloning Stem Cells 10: 495-502.

KUIJK EW, VAN TOL LT, VAN DE VELDE H, WUBBOLTS R, WELLING M, GEIJSEN N, ROELEN BA (2012). The roles of FGF and MAPK signaling in the segregation of the epiblast and hypoblast lineages in bovine and human embryos. Development 139: 871-882.

KUMARS, TAMURAK, NEI M (2004). Mega3: integrated software for molecular evolutionary genetics analysis and sequence alignment. Brief Bioinform 5: 150-163.

LEE DF, SU J, ANG YS, CARVAJAL-VERGARAX, MULERO-NAVARRO S, PEREIRA CF, GINGOLD J, WANG HL, ZHAO R, SEVILLA A, DARR H, WILLIAMSON AJ, CHANG B, NIU X, AGUILO F, FLORES ER, SHER YP, HUNG MC, WHETTON AD, GELB BD, MOORE KA, SNOECK HW, MA'AYAN A, SCHANIEL C, LEMISCHKA IR (2012). Regulation of Embryonic and Induced Pluripotency by Aurora Kinase-p53 Signaling. Cell Stem Cell 11: 179-194.

LEVENSTEIN ME, LUDWIG TE, XU RH, LIANAS RA, VANDENHEUVEL-KRAMER K, MANNING D, THOMSON JA (2006). Basic fibroblast growth factor support of human embryonic stem cell self-renewal. Stem Cells 24: 568-574.

LI P, TONG C, MEHRIAN-SHAI R, JIA L, WU N, YAN Y, MAXSON RE, SCHULZE EN, SONG H, HSIEH CL, PERA MF, YING QL (2008). Germline competent embryonic stem cells derived from rat blastocysts. Cell 135: 1299-1310.

LI Z, FEI T, ZHANG J, ZHU G, WANG L, LU D, CHI X, TENG Y, HOU N, YANG X, ZHANG H, HAN JD, CHEN YG (2012). BMP4 Signaling Acts via dual-specificity phosphatase 9 to control ERK activity in mouse embryonic stem cells. Cell Stem Cell 10: 171-182.

MASUI S, NAKATAKE Y, TOYOOKA Y, SHIMOSATO D, YAGI R, TAKAHASHI K, OKOCHI H, OKUDA A, MATOBA R, SHAROV AA, KO MS, NIWA H (2007). Pluripotency governed by Sox2 via regulation of Oct3/4 expression in mouse embryonic stem cells. Nat Cell Biol 9: 625-635.

MCLEAN AB, D'AMOUR KA, JONES KL, KRISHNAMOORTHY M, KULIK MJ, REYNOLDS DM, SHEPPARD AM, LIU H, XUY, BAETGE EE, DALTON S (2007). Activin a efficiently specifies definitive endoderm from human embryonic stem cells only when phosphatidylinositol 3-kinase signaling is suppressed. Stem Cells 25: 29-38.

MARUOTTI J, MUÑOZ M, DEGRELLE SA, GÓMEZ E, LOUET C, DÍEZ C, DE LONGCHAMP PH, BROCHARD V, HUE I, CAAMAÑO JN, JOUNEAU A (2012). Efficient derivation of bovine embryonic stem cells needs more than active core pluripotency factors. Mol Reprod Dev 79: 461-477.

MIYABAYASHI T, TEO JL, YAMAMOTO M, MCMILLAN M, NGUYEN C, KAHN M (2007). Wnt/beta-catenin/CBP signaling maintains long-term murine embryonic stem cell pluripotency. Proc Natl Acad Sci USA 104: 5668-5673.

MIYANARI Y, TORRES-PADILLA ME (2012). Control of ground-state pluripotency by allelic regulation of Nanog. Nature 483: 470-473.

NAJM FJ, CHENOWETH JG, ANDERSON PD, NADEAU JH, REDLINE RW, MCKAY RD, TESAR PJ (2011). Isolation of epiblast stem cells from preimplantation mouse embryos. Cell Stem Cell 8: 318-325.

NAKANISHI M, KURISAKI A, HAYASHI Y, WARASHINA M, ISHIURA S, KUSUDAFURUE M, ASASHIMA M (2009). Directed induction of anterior and posterior primitive streak by Wnt from embryonic stem cells cultured in a chemically defined serum-free medium. FASEB J 23: 114-122.

NAKATAKE Y, FUKUI N, IWAMATSU Y, MASUI S, TAKAHASHI K, YAGI R, YAGI K, MIYAZAKI J, MATOBA R, KO MS, NIWA H (2006). KIf4 cooperates with Oct3/4 and Sox2 to activate the Lefty1 core promoter in embryonic stem cells. Mol Cell Biol 26: 7772-7782.
NICHOLS J, SILVA J, ROODE M, SMITH A (2009). Suppression of Erk signalling promotes ground state pluripotency in the mouse embryo. Development 136: 3215-3222.

NICHOLS J, SMITH A (2009). Naive and primed pluripotent states. Cell Stem Cell 4: 487-492.

NICHOLS J, SMITH A (2011). The origin and identity of embryonic stem cells. Development 138: 3-8.

NIWA H, BURDON T, CHAMBERS I, SMITH A (1998). Self-renewal of pluripotent embryonic stem cells is mediated via activation of STAT3. Genes Dev 12: 2048-2060.

NIWAH, MIYAZAKI J, SMITHAG (2000). Quantitative expression of Oct-3/4 defines differentiation, dedifferentiation or self-renewal of ES cells. Nat Genet24:372-376.

OGAWA K, SAITO A, MATSUI H, SUZUKI H, OHTSUKA S, SHIMOSATO D, MORISHITA Y, WATABE T, NIWA H, MIYAZONO K (2007). Activin-Nodal signaling is involved in propagation of mouse embryonic stem cells. J Cell Sci 120: 55-65.

PALING NR, WHEADON H, BONE HK, WELHAM MJ (2004). Regulation of embryonic stem cell self-renewal by phosphoinositide 3-kinase-dependent signaling. J Biol Chem 279: 48063-48070.

PERA MF, TAM PP (2010). Extrinsic regulation of pluripotent stem cells. Nature 465: 713-720.

QI X, LITG, HAO J, HU J, WANG J, SIMMONS H, MIURAS, MISHINA Y, ZHAO GQ (2004). BMP4 supports self-renewal of embryonic stem cells by inhibiting mitogenactivated protein kinase pathways. Proc Natl Acad Sci USA 101: 6027-6032.

RAJENDRAN G, DUTTAD, HONG J, PAULA, SAHAB, MAHATO B, RAY S, HOME P, GANGULYA, WEISS ML, PAULS (2013). Inhibition of protein kinase C signaling maintains rat embryonic stem cell pluripotency. J Biol Chem 288: 24351-24362.

ROODE M, BLAIR K, SNELL P, ELDER K, MARCHANT S, SMITH A, NICHOLS J (2012). Human hypoblast formation is not dependent on FGF signalling. Dev Biol 361: 358-363.

SAITO S, UGAI H, SAWAI K, YAMAMOTO Y, MINAMIHASHI A, KUROSAKA K, KOBAYASHI Y, MURATA T, OBATA Y, YOKOYAMA K (2002). Isolation of embryonic stem-like cells from equine blastocysts and their differentiation in vitro. FEBS Lett 531: 389-396.

SATO N, MEIJER L, SKALTSOUNIS L, GREENGARD P, BRIVANLOU AH (2004). Maintenance of pluripotency in human and mouse embryonic stem cells through activation of Wnt signaling by a pharmacological GSK-3-specific inhibitor. Nat Med 10: 55-63.

SINGH AM, REYNOLDS D, CLIFF T, OHTSUKA S, MATTHEYSES AL, SUN Y, MENENDEZ L, KULIK M, DALTON S (2012). Signaling network crosstalk in human pluripotent cells: a Smad2/3-regulated switch that controls the balance between self-renewal and differentiation. Cell Stem Cell 10: 312-326.

SMITH AG, HEATH JK, DONALDSON DD, WONG GG, MOREAU J, STAHL M, ROGERSD (1988). Inhibition of pluripotential embryonic stem cell differentiation by purified polypeptides. Nature 336: 688-690.

TACHIBANA M, SPARMAN M, RAMSEY C, MA H, LEE HS, PENEDO MC, MITALIPOV S (2012). Generation of chimeric rhesus monkeys. Cell 148: 285-295.

TAKAHASHI K, TANABE K, OHNUKI M, NARITA M, ICHISAKA T, TOMODA K, YAMANAKA S (2007). Induction of pluripotent stem cells from adult human fibroblasts by defined factors. Cell 131: 861-872.

TAN T, TANG X, ZHANG J, NIU Y, CHEN H, LI B, WEI Q, JI W (2011). Generation of trophoblast stem cells from rabbit embryonic stem cells with BMP4. PLoS One 6: e17124.

TELUGU BP, EZASHI T, SINHA S, ALEXENKO AP, SPATE L, PRATHER RS, ROBERTS RM (2011). Leukemia inhibitory factor (LIF)-dependent, pluripotent stem cells established from inner cell mass of porcine embryos. $J$ Biol Chem 286: 28948-28953.

TESAR PJ, CHENOWETH JG, BROOK FA, DAVIES TJ, EVANS EP, MACK DL, GARDNER RL, MCKAY RD (2007). New cell lines from mouse epiblast share defining features with human embryonic stem cells. Nature 448: 196-199.

THOMPSON JD, HIGGINS DG, GIBSON TJ (1994). Clustal W: improving the sensitivity of progressive multiple sequence alignment through sequence weighting, position specific gap penalties and weight matrix choice. Nucleic Acids Res 22: 4673-4680.

THOMSON JA, ITSKOVITZ-ELDOR J, SHAPIRO SS, WAKNITZ MA, SWIERGIEL JJ, MARSHALL VS, JONES JM (1998). Embryonic stem cell lines derived from human blastocysts. Science 282: 1145-1147. 
THOMSON JA, KALISHMAN J, GOLOS TG, DURNING M, HARRIS CP, BECKER RA, HEARN JP (1995). Isolation of a primate embryonic stem cell line. Proc Nat Acad Sci USA 92: 7844-7848.

UEDA S, KAWAMATA M, TERATANI T, SHIMIZU T, TAMAI Y, OGAWA H, HAYASHI $\mathrm{K}$, TSUDA H, OCHIYA T (2008). Establishment of rat embryonic stem cells and making of chimera rats. PLoS One 3: e2800.

VALLIER L, MENDJAN S, BROWN S, CHNG Z, TEO A, SMITHERS LE, TROTTER MW, CHO CH, MARTINEZ A, RUGG-GUNN P, BRONS G, PEDERSEN RA (2009a). Activin/Nodal signalling maintains pluripotency by controlling Nanog expression. Development 136: 1339-1349.

VALLIER L, TOUBOUL T, CHNG Z, BRIMPARI M, HANNAN N, MILLAN E, SMITHERS LE, TROTTER M, RUGG-GUNN P, WEBER A, PEDERSEN RA (2009b). Early cell fate decisions of human embryonic stem cells and mouse epiblast stem cells are controlled by the same signalling pathways. PLoS One 4: e6082.

VAN OOSTEN AL, COSTA Y, SMITH A, SILVA JC (2012). JAK/STAT3 signalling is sufficient and dominant over antagonistic cues for the establishment of naive pluripotency. Nat Commun 3: 817.

WANG S, SHEN Y, YUAN X, CHEN K, GUO X, CHEN Y, NIU Y, LI J, XU RH, YAN $X, Z H O U Q, J I W(2008)$. Dissecting signaling pathways that govern self-renewal of rabbit embryonic stem cells. J Biol Chem 283: 35929-35940.

WATANABE S, UMEHARA H, MURAYAMA K, OKABE M, KIMURA T, NAKANO T
(2006). Activation of Akt signaling is sufficient to maintain pluripotency in mouse and primate embryonic stem cells. Oncogene 25: 2697-2707.

XU RH, CHEN X, LI DS, LI R, ADDICKS GC, GLENNON C, ZWAKA TP, THOMSON JA (2002). BMP4 initiates human embryonic stem cell differentiation to trophoblast. Nat Biotechnol 20: 1261-1264.

YING QL, NICHOLS J, CHAMBERS I, SMITHA (2003). BMP induction of Id proteins suppresses differentiation and sustains embryonic stem cell self-renewal in collaboration with STAT3. Cell 115: 281-292.

YING QL, WRAY J, NICHOLS J, BATLLE-MORERA L, DOBLE B, WOODGETT J, COHEN P, SMITH A (2008). The ground state of embryonic stem cell selfrenewal. Nature 453: 519-523.

YU PB, BEPPU H, KAWAI N, LI E, BLOCH KD (2005). Bone morphogenetic protein (BMP) type II receptor deletion reveals BMP ligand-specific gain of signaling in pulmonary artery smooth muscle cells. J Biol Chem 280: 24443-24450

ZHAO Y, LIN J, WANG L, CHEN B, ZHOU C, CHEN T, GUO M, HE S, ZHANG N, LIU C, LIU M, HUANG J (2011). Derivation and characterization of ovine embryonic stem-like cell lines in semi-defined medium without feeder cells. $J$ Exp Zool A Ecol Genet Physiol 315: 639-648.

ZHONG Z, WEN Z, DARNELL JE JR (1994). Stat3: a STAT family member activated by tyrosine phosphorylation in response to epidermal growth factor and interleukin-6. Science 264: 95-98. 


\section{Further Related Reading, published previously in the Int. J. Dev. Biol.}

Signaling pathways during maintenance and definitive endoderm differentiation of embryonic stem cells.

Lina Sui, Luc Bouwens and Josué K. Mfopou.

Int. J. Dev. Biol. (2013) 57: 1-12

Rediscovering pluripotency: from teratocarcinomas to embryonic stem cells.

Ivana Barbaric and Neil J. Harrison.

Int. J. Dev. Biol. (2012) 56: 197-206

Reprogramming cell fate to pluripotency: the decision-making signalling pathways. Daniela Sanges and Maria-Pia Cosma.

Int. J. Dev. Biol. (2010) 54: 1575-1587

Porcine induced pluripotent stem cells analogous to naïve and primed embryonic stem cells of the mouse.

Bhanu Prakash V.L. Telugu, Toshihiko Ezashi and R. Michael Roberts.

Int. J. Dev. Biol. (2010) 54: 1703-1711

Natural and artificial routes to pluripotency.

Winfried H. Krueger, Lindsey C. Swanson, Borko Tanasijevic and Theodore P. Rasmussen. Int. J. Dev. Biol. (2010) 54: 1545-1564

5 yr ISI Impact Factor $(2011)=2.959$
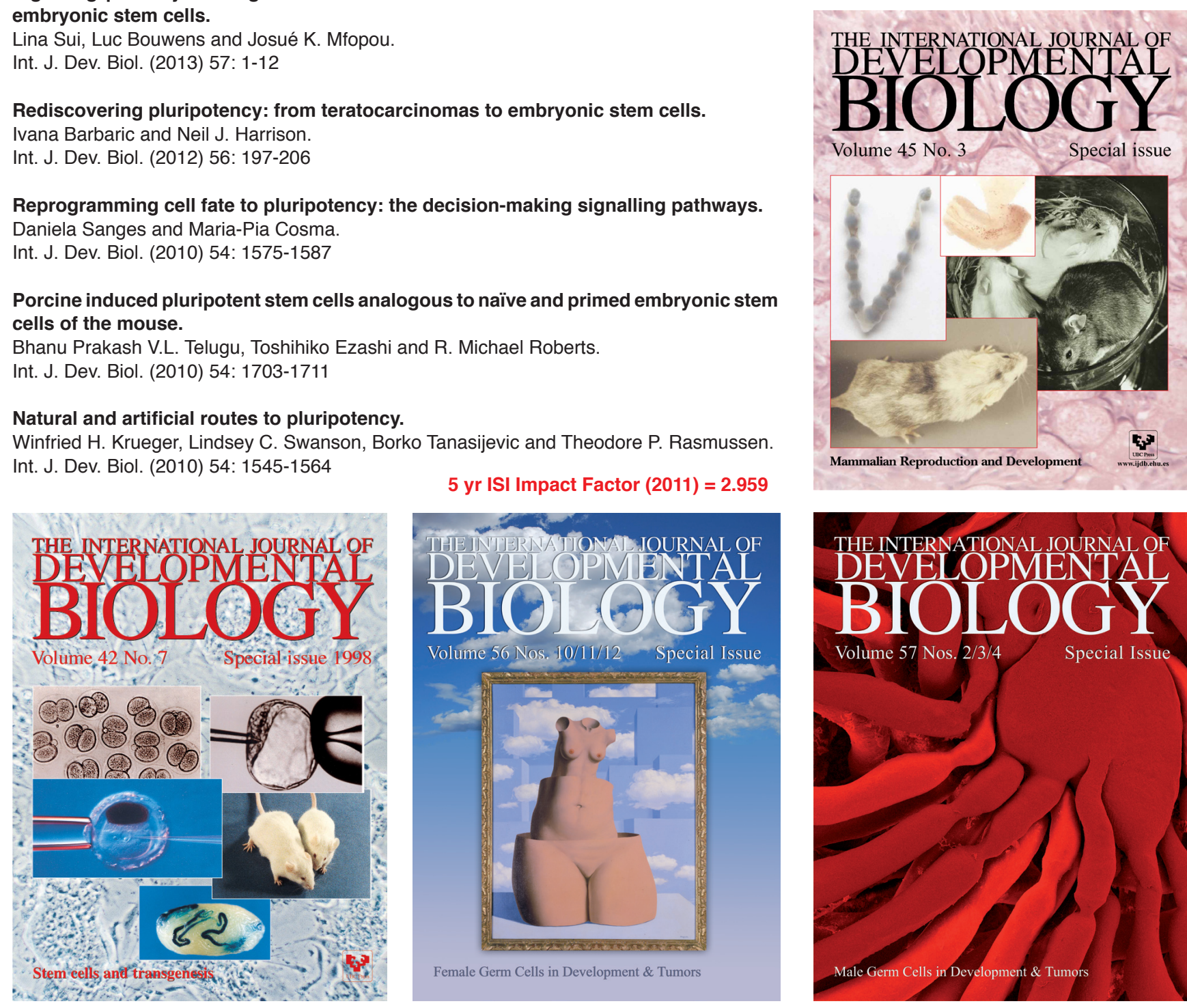

Female Germ Cells in Development \& Tumors

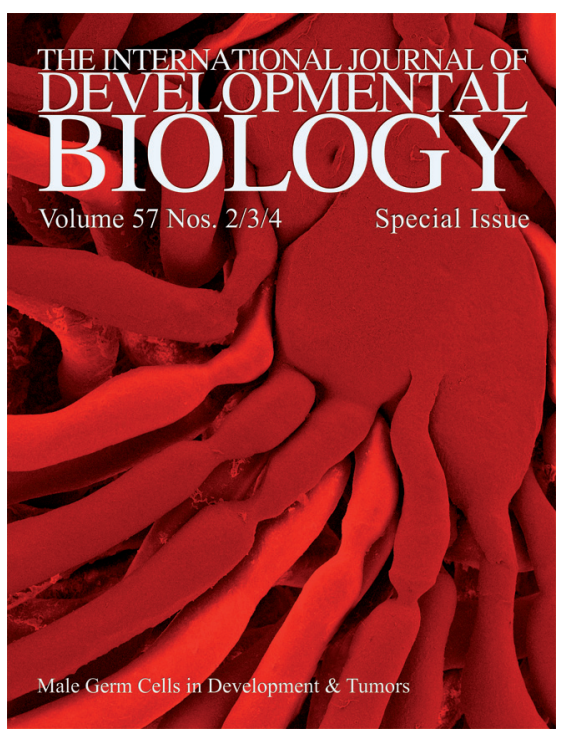

